\title{
Local and Remote Ischemia-Reperfusion Injury Is Mitigated in Mice Overexpressing Human C1 Inhibitor
}

\author{
D. Inderbitzin ${ }^{a} \quad$ G. Beldia I. Avitala $\quad$ G. Vincib $\quad$ D. Candinasa
}

aDepartment of Visceral and Transplant Surgery, University Hospital Bern, Bern, Switzerland; b Institut National de la Santé et de la Recherche Médicale E0021, Département de Biologie du Développement, Unité 'Reproduction, Fertilité et Populations', Institut Pasteur, Paris, France

\section{Key Words}

Ischemia-reperfusion injury · Complement · C1 inhibitor - Transgenic mouse - Endothelial disruption . Permeability index

\begin{abstract}
Activation of the classical complement pathway is crucially involved in complement-mediated endothelial cell damage in ischemia-reperfusion injury. $\mathrm{Cl}$ inhibitor is the only known physiological inhibitor of classical complement pathway activation. Transgenic mice overexpressing human $\mathrm{Cl}$ inhibitor were used in a surgical lower torso and a liver ischemia-reperfusion model. Organspecific endothelial disruption was determined by 1251tagged albumin extravasation. In the lower torso ischemia-reperfusion model, transgenic mice overexpressing the $\mathrm{Cl}$ inhibitor were protected in the muscle and the lungs from endothelial cell damage. In the liver ischemia-reperfusion model, endothelial cell integrity was preserved in transgenic animals in the liver, the gut and the lungs. Our data indicate that inhibiting complement activation by a transgenic approach is effective in protection against ischemia-reperfusion injury.
\end{abstract}

Copyright @2004S. Karger AG, Base

\section{KARGER}

Fax +41613061234

E-Mail karger@karger.ch

www. karger.com
(C) 2004 S. Karger AG, Basel

0014-312X/04/0363-0142\$21.00/0

www. karger.com/esr
Accessible online at:

\section{Introduction}

Tissue damage due to ischemia-reperfusion injury is of crucial clinical importance in organ transplantation as well as in a variety of disorders like hemorrhagic shock, myocardial infarction, stroke, and embolic disease [1-4]. The pathophysiological key events in ischemia-reperfusion injury have been characterized over the past 30 years as complement activation and neutrophil stimulation [5, 6]. The complement system is activated during ischemiareperfusion through three different pathways, the classical, the alternative, and the lectin pathway, which results in the formation of the membrane attack complex (C5b-9) and ultimately endothelial cell disruption. During complement activation anaphylatoxins like C5a and C3a cause chemotaxis of leukocytes, degranulation of phagocytic cells, and a further increase of vascular permeability $[7,8]$.

An attractive approach to modify complement activation consists in the application of the natural complement regulator $\mathrm{C} 1$ inhibitor. $\mathrm{C} 1$ inhibitor is the only known physiological inhibitor of the classical complement cascade activation [9]. It belongs to the superfamily of serinprotease inhibitors and is a heavily glycosylated serum protein of $105 \mathrm{kD}[10,11]$. It inhibits the antibody-depen-
D. Inderbitzin, MD

Department of Visceral and Transplant Surgery

University Hospital Bern

CH-3010 Bern (Switzerland)

Tel. +41 3163241 10, Fax +41 3138247 72, daniel.inderbitzin@insel.ch 
dent formation of $\mathrm{C} 1$ by steric interaction with the $\mathrm{C} 1-$ subunits $\mathrm{C} 1 \mathrm{r}$ and $\mathrm{C} 1 \mathrm{~s}$. Furthermore, it interferes with the lectin pathway by inhibition of the serum mannose-binding lectin-associated proteases [12]. Additional proteases inactivated by $\mathrm{C} 1$ inhibitor include activated coagulation factors XI and XII, kallikrein, plasmin, and tissue-type plasminogen activator.

The classical complement pathway cascade due to natural-antibody-mediated $\mathrm{C} 1$ activation is important in ischemia-reperfusion injury [13-15] and $\mathrm{C} 1$ inhibitor can effectively control this activation. In normal serum $\mathrm{C} 1$ inhibitor is present in a 7-fold molar excess of $\mathrm{C} 1$. Additional increase to more than 10-fold molar excess of $\mathrm{C} 1$ inhibitor blocks $\mathrm{C}$ activation completely [9].

The known minor variations of $\mathrm{C} 1$ inhibitor between different species [16] do not impede the functionality of the protein as shown by the successful use of the human $\mathrm{C} 1$ inhibitor in feline [17, 18] canine [19] and rodent [20, 21] animal models. Complement inhibition in the mouse by human $\mathrm{C} 1$ inhibitor was demonstrated in vitro [22] and recently in vivo in a study of lower torso ischemiareperfusion injury in wild-type mice [21].

Due to the proven protective in vivo effect of human C1 inhibitor in ischemia-reperfusion experimentation [21] but also because of the short half-life of administered $\mathrm{C} 1$ inhibitor [16], it seemed attractive to test the capacity of human $\mathrm{C} 1$ inhibitor overexpressing transgenic mice [11] to resist complement-mediated endothelial cell disruption in ischemia-reperfusion injury. Using the wellestablished method of intravenous ${ }^{125}$ I-labelled bovine albumin injection, the integrity of tissue-specific endothelium is assessed by the use of the permeability index, and a destroyed vascular endothelium is characterized by elevated permeability index values due to extravasation of tagged albumin [2, 23, 24].

Tissue-specific radioactivity was compared between three experimental groups: Transgenic, human $\mathrm{C} 1$ inhibitor overexpressing mice with ischemia-reperfusion injury, wild-type control animals with ischemia-reperfusion injury, and sham-operated control mice in a surgical lower torso ischemia-reperfusion model and a liver ischemiareperfusion model.

\section{Material and Methods}

Human C1 Inhibitor Overexpressing Transgenic Mice

All animal experimentation was approved by the local committee for animal welfare in accordance with the European Convention on Animal Care.

C1 Inhibitor Overexpression Mitigates

Ischemia-Reperfusion Injury
Transgenic human $\mathrm{C} 1$ inhibitor overexpressing mice were generated as described and were kindly prepared by G. Vinci, Institut Pasteur, Paris, France [11]. Only animals with high plasma expression of human $\mathrm{C} 1$ inhibitor (i.e. $1-2 \mathrm{mg} / \mathrm{ml}$ ) were used for ischemia-reperfusion experimentation.

\section{Anesthesia}

Adult SPF C57B/6 mice and transgenic human $\mathrm{C} 1$ inhibitor overexpressing mice, 25-32 g, were kept under standard conditions for laboratory animals with a 12-hour light/dark cycle. They were fed standard chow and given water ad libitum. Operative procedures were performed under general intraperitoneal (i.p.) anesthesia with an initial combination of ketamine $(0.065 \mathrm{mg} / \mathrm{g}$ body weight; Keta$1 \mathrm{lar}^{\circledR}$, Parke Davis, Baar, Switzerland), xylazine $(0.013 \mathrm{mg} / \mathrm{g}$ body weight; Rompun ${ }^{\circledR}$, Bayer AG, Leverkusen, Germany) and acepromazine $\left(0.002 \mathrm{mg} / \mathrm{g}\right.$ body weight; Sedalin ${ }^{\circledR}$, Chassot GmbH, Ravensburg, Germany). Anesthesia was then maintained by i.p. application of $1 \mathrm{mg}$ ketamine, $0.2 \mathrm{mg}$ of xylazine and $0.03 \mathrm{mg}$ of acepromazine using an i.p. catheter through the right lateral abdominal wall every $90 \mathrm{~min}$. Ringer's solution was administered $(0.2 \mathrm{ml})$ i.p. every hour.

\section{Surgical Procedures}

\section{Lower Torso Ischemia-Reperfusion}

Animals were immobilized in a supine position and the abdomen entered through a midline incision. The infrarenal aorta and vena cava were dissected free and cross-clamped in transgenic (group A1) and wild-type control mice (group B1) by the use of a permanent Yasargil-Aneurysm-Clip (FD 582; Aesculap-Werke AG, Tuttlingen, Germany). Complete clamping was verified under the operating microscope $(\times 20)$. Sham-operated control animals (group C1) underwent a similar procedure but did not undergo ischemia. An i.p. catheter (Abbocath-T, $20 \mathrm{G} \times 32 \mathrm{~mm}$; Abbott Ireland Ltd., Sligo, Ireland) was placed trough the right abdominal wall and the laparotomy temporarily closed by disposable skin staples (Precise DS-25; $3 \mathrm{M})$. Animals were kept under anesthesia on a heating pad $\left(36.9^{\circ} \mathrm{C}\right)$ in a left lateral position for $2 \mathrm{~h}$. Skin staples were then removed and complete clamping as well as full reperfusion after removal of the clip was again checked under microscopic view $(\times 20)$. For the determination of endothelial integrity animals received $1.0 \mu \mathrm{Ci}{ }^{125}$ I-labelled bovine albumin (specific activity: $1 \mathrm{mCi} / \mathrm{mg}$; ICN Pharmaceuticals Inc., Costa Mesa, Calif., USA) in $0.1 \mathrm{ml}$ Ringer's lactate injected into the infrarenal vena cava. The laparotomy incision was closed again and reperfusion allowed for $3 \mathrm{~h}$. After reopening of the laparotomy, terminal blood samples were taken from the vena cava to determine background radiation and organs harvested in the following manner. To expose the thoracic cavity, a bilateral longitudinal thoracotomy was performed. The inferior vena cava, the descending aorta, and the left atrial appendage were transected and the pulmonary artery intubated trough an incision in the conus pulmonalis of the right ventricle. The pulmonary circulation was then flushed with $3 \mathrm{ml}$ of Ringer's lactate by gravity infusion at $10 \mathrm{~cm} \mathrm{H}_{2} \mathrm{O}$ to omit background radiation. Lungs and heart were removed en bloc.

Permeability Index

Both lungs, a liver specimen of the median lobe, a gut specimen of the small intestine, both kidneys and quadriceps and triceps muscles from the right lower extremity were harvested, weighted, the radioactivity measured in the $\gamma$-counter (counts per minute (cpm); Cobra II, Auto-Gamma; Packard Instrument Company, Meriden, Conn.,

Eur Surg Res 2004;36:142-147 


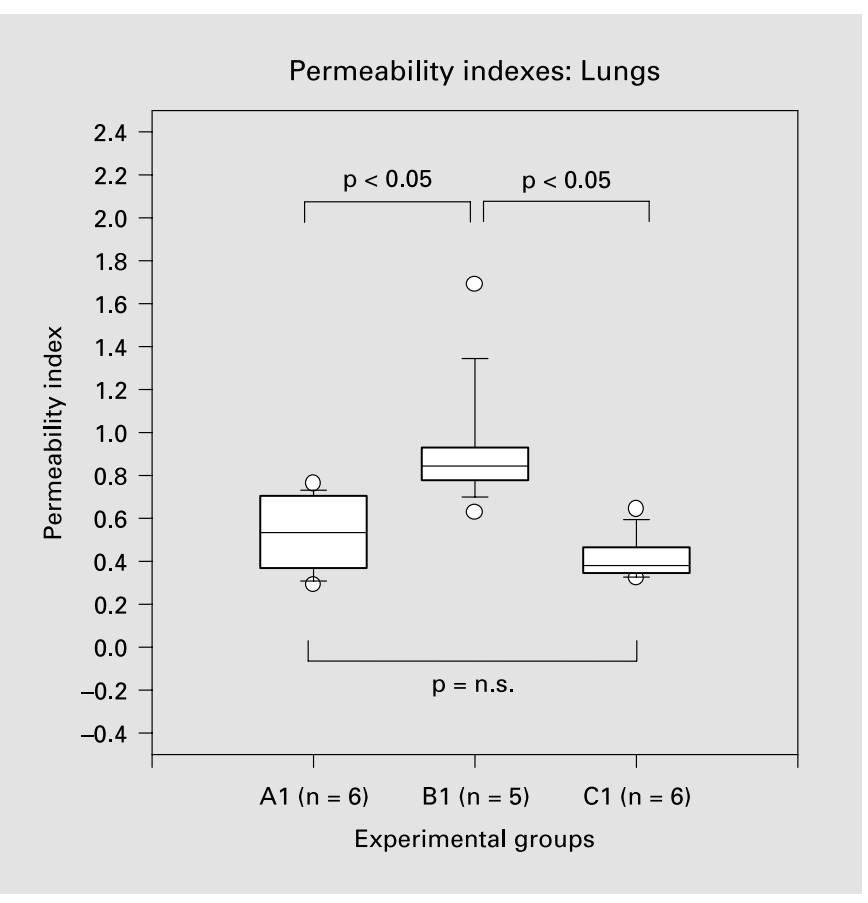

Fig. 1. Tukey box plot: Depicted are permeability index values of pulmonary tissue from animals after $2 \mathrm{~h}$ of lower torso ischemia and $3 \mathrm{~h}$ of reperfusion injury. The extent of the box indicates the 25 th and 75th percentiles. The line inside the box shows the value of the 50th percentile. Capped bars indicate the 10th and 90th percentiles and symbols mark the 5th and 95th percentiles. Remote pulmonary ischemia-reperfusion injury is reduced in human $\mathrm{C} 1$ inhibitor overexpressing transgenic mice (group A1). No significant difference to sham-operated animals (group C1) is detectable, while wild-type control animals (group B1) show clear signs of endothelial disruption.

USA) and then dried to a constant weight at $85^{\circ} \mathrm{C}$ for $72 \mathrm{~h}$. The permeability index (PI) is determined by the amount of extravasation of ${ }^{125}$ I-labelled albumin and reflects a direct functional measurement of endothelial integrity. Permeability index values were calculated by the ratio (cpm/mg dry tissue)/(cpm/mg blood) as described $[23,24]$.

\section{Liver Ischemia-Reperfusion}

In a second experimental series, transgenic (group A2) and wildtype control mice (group B2) were subjected to liver ischemia-reperfusion, while sham-operated animals (group C2) did not undergo vascular clamping ( $n=4$ in each group). The abdomen was entered under general i.p. anesthesia and the entire hepatoduodenal ligament was cross-clamped for $30 \mathrm{~min}$. Complete clamping as well as reperfusion after removal of the clip was then checked under microscopic view $(\times 20)$ and $1.0 \mu \mathrm{Ci}^{125}$ I-labelled bovine albumin injected intravenously. The laparotomy incision was temporarily closed and reperfusion allowed for $2 \mathrm{~h}$. Tissue harvest and preparation was performed as described above. Permeability index values were then calculated.
Table 1. Permeability index values after lower torso ischemia $(2 \mathrm{~h})$ and reperfusion $(3 \mathrm{~h})$ injury

\begin{tabular}{llll}
\hline Organ & $\begin{array}{l}\text { Group A1 } \\
\text { (transgenic) }\end{array}$ & $\begin{array}{l}\text { Group B1 } \\
\text { (wild type) }\end{array}$ & $\begin{array}{l}\text { Group C1 } \\
\text { (sham) }\end{array}$ \\
\hline Lung & $0.53 \pm 0.18$ & $0.92 \pm 0.29$ & $0.42 \pm 0.10$ \\
Skeletal muscle & $0.08 \pm 0.02$ & $0.10 \pm 0.02$ & $0.06 \pm 0.01$ \\
Liver & $0.46 \pm 0.11$ & $0.51 \pm 0.05$ & $0.49 \pm 0.12$ \\
Gut & $0.06 \pm 0.03$ & $0.07 \pm 0.03$ & $0.06 \pm 0.03$ \\
Kidney & $0.97 \pm 0.43$ & $0.90 \pm 0.07$ & $1.07 \pm 0.45$ \\
\hline
\end{tabular}

Mean of permeability index values $(\mathrm{PI} \pm \mathrm{SD}$ ) after lower torso ischemia $(2 \mathrm{~h})$ and reperfusion $(3 \mathrm{~h})$ calculated from specific organ radioactivity (e.g. lung, skeletal muscle, liver, kidney, and gut). The permeability index allows a direct quantification of endothelial integrity.

\section{Statistical Analysis}

Results are expressed as mean \pm SD. Data were analyzed statistically by Jandel Scientific Software (Jandel Scientific 1.0; San Raffael, Calif., USA). One-way analysis of variance was performed to compare groups and the Student-Newman-Keuls method applied for pairwise multiple comparison procedures. Kruskal-Wallis testing and pairwise comparison according to Dunn were used for non-normally distributed data. The significance level was set at $\mathrm{p}<0.05$.

\section{Results}

\section{Lower Torso Ischemia-Reperfusion}

Animals from all three experimental groups $(\mathrm{n}=18)$ survived $5 \mathrm{~h}$ of narcosis.

In the skeletal muscle of the lower extremity, $\mathrm{C} 1$ inhibitor overexpression decreased the local endothelial cell damage significantly (group A1, PI $=0.08 \pm 0.02$ ) when compared to wild-type control animals (group B1, PI = $0.10 \pm 0.02)$. No difference was seen between transgenic and sham-operated control mice (group C1, PI $=0.06 \pm$ $0.01)$.

In the lungs of transgenic mice (group A1, PI $=0.53 \pm$ $0.18), \mathrm{C} 1$ inhibitor overexpression protected the vascular endothelium from remote ischemia-reperfusion injury as seen by a permeability index that was significantly lower than in wild-type control animals (group B1, PI = $0.92 \pm$ 0.29 ) and not different to sham-operated controls (group $\mathrm{C} 1, \mathrm{PI}=0.42 \pm 0.10$ ) (fig. 1 ).

In the liver, the gut, and the kidney, endothelial integrity after lower torso ischemia-reperfusion was unaltered and no difference in the permeability index between the three experimental groups was observed (table 1). 
Table 2. Permeability index values after liver ischemia (30 min) and reperfusion $(2 \mathrm{~h})$ injury

\begin{tabular}{llll}
\hline Organ & $\begin{array}{l}\text { Group A2 } \\
\text { (transgenic) }\end{array}$ & $\begin{array}{l}\text { Group B2 } \\
\text { (wild type) }\end{array}$ & $\begin{array}{l}\text { Group C2 } \\
\text { (sham) }\end{array}$ \\
\hline Lung & $0.26 \pm 0.01$ & $0.28 \pm 0.04$ & $0.18 \pm 0.04$ \\
Liver & $0.46 \pm 0.10$ & $0.78 \pm 0.07$ & $0.50 \pm 0.07$ \\
Gut & $0.09 \pm 0.02$ & $0.15 \pm 0.07$ & $0.07 \pm 0.01$ \\
\hline
\end{tabular}

Mean of permeability index values $(\mathrm{PI} \pm \mathrm{SD})$ after liver ischemia for $30 \mathrm{~min}$ and reperfusion for $2 \mathrm{~h}$.

\section{Liver Ischemia-Reperfusion}

In the series of hepatic ischemia-reperfusion all animals from the three experimental groups $(n=12)$ survived $2.5 \mathrm{~h}$ of narcosis.

We observed significant local hepatic endothelial cell protection against ischemia-reperfusion injury in transgenic $\mathrm{C} 1$ inhibitor overexpressing animals (group A2, PI = $0.46 \pm 0.10$ ) when compared to wild-type control animals (group B2, PI $=0.78 \pm 0.07$ ). No significant difference to sham-operated animals of group $\mathrm{C} 2(\mathrm{PI}=0.50 \pm 0.07)$ was evident (fig. 2).

Clamping of the entire hepatoduodenal ligament caused portal blood flow obstruction. As a result significant elevation of the permeability index values in the gut of wild-type control animals (group B2, PI $=0.15 \pm 0.07$ ) were detected when compared to transgenic animals (group A2, PI $=0.09 \pm 0.02$ ) or sham-operated controls (group C2, PI = $0.07 \pm 0.01$ ) (table 2).

The permeability index values in the lungs after $30 \mathrm{~min}$ of liver ischemia and $2 \mathrm{~h}$ of reperfusion were statistically not different between the transgenic mice (group A2, PI = $0.26 \pm 0.01$ ) and the sham-operated animals (group C2, $\mathrm{PI}=0.18 \pm 0.04$ ), whereas the permeability index values in the wild-type control mice was elevated (group B2, PI = $0.28 \pm 0.04$ ) indicating remote ischemia-reperfusion injury in this experimental group (table 2).

\section{Discussion}

Ischemia-reperfusion of the lower torso results in complement-mediated local and remote endothelial cell and organ injury [2]. The vascular permeability index allows a fast and accurate determination of organ-specific endothelial integrity $[23,24]$. Local (i.e. skeletal muscle, liver) and remote (i.e. lung, kidney, gut) endothelial disruption

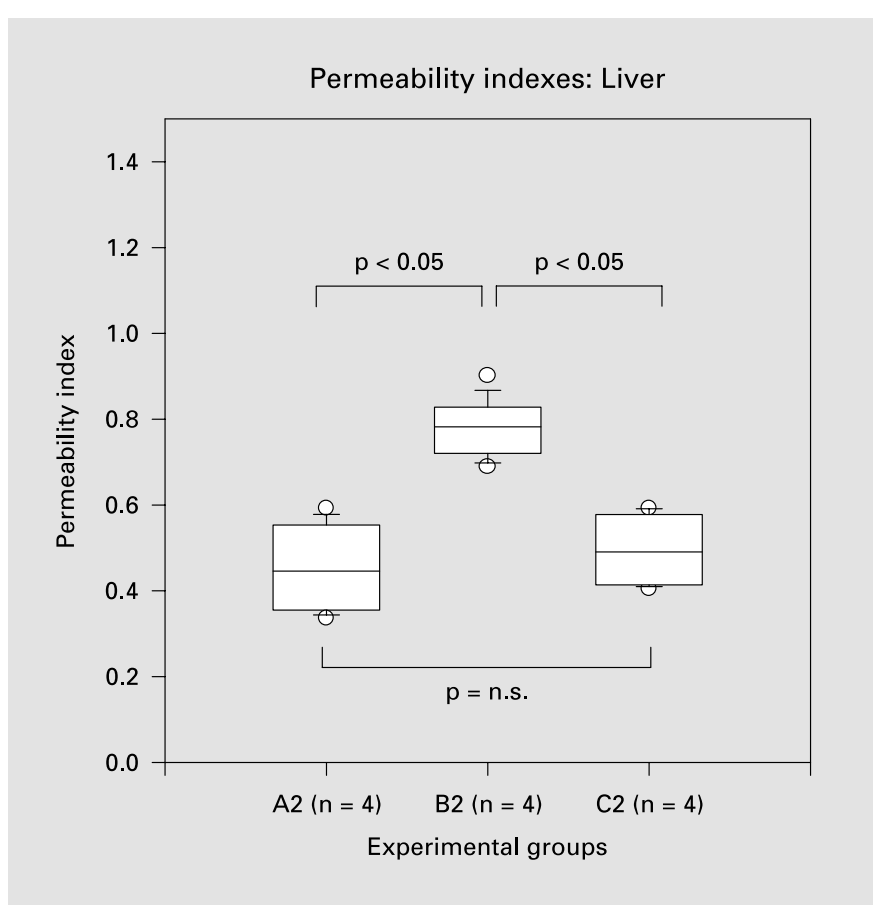

Fig. 2. Hepatic permeability index values in a Tukey box plot after 30 min of liver ischemia and $2 \mathrm{~h}$ of reperfusion injury. Ischemiareperfusion injury is precluded by $\mathrm{C} 1$ inhibitor overexpression (group A2) as there is no significant difference to sham-operated animals (group C2).

can be assessed simultaneously in different models of ischemia-reperfusion injury. This approach helps to further elucidate organ-specific endothelial cell injury resulting from ischemia-reperfusion of local and distant organs.

We chose a severe lower torso ischemia-reperfusion injury model $[21,25]$. While the mortality of $105 \mathrm{~min}$ of ischemia followed by reperfusion has been reported to be between 10 [23, 25] and 57\% in mice [21], all animals of our series survived $120 \mathrm{~min}$ of ischemia and $180 \mathrm{~min}$ of reperfusion $(n=12)$. In contrast to the work of Nielsen et al. [21], we substituted fluid and electrolytes continuously (i.e. $0.2 \mathrm{ml}$ Ringer's solution hourly for an adult mouse). During long-term narcosis in lower torso ischemia-reperfusion experimentation, fluid balance seems essential for small animal survival.

In a nonsurgical ischemia-reperfusion injury mouse model $[15,23]$ of $2 \mathrm{~h}$ of hindleg ischemia by external compression followed by $3 \mathrm{~h}$ of reperfusion after injection of ${ }^{125}$ I-tagged albumin, permeability index values in sham control animals were comparable to sham-operated mice from our series. However, in the experimental group of 
Kyriakides et al. [23] the application of external compression caused a massive endothelial disruption and permeability index values of $2.53 \pm 0.11$, while in our series after infrarenal vascular occlusion a moderate but significant elevation of the vascular permeability was observed in wild-type animals $(0.10 \pm 0.02)$. Transabdominal induction of lower torso ischemia provides direct evidence of complete clamping and allows convincing visualization of reperfusion. Furthermore, the surgical approach excludes local muscular damage on the extremity examined.

Pulmonary endothelial cell disruption after radioactively labelled albumin injection is either measurable by comparing radioactivity in the aspirate after bronchoalveolar lavage within experimental groups $[26,27]$ or by determination of whole lung radioactivity after flushing of the pulmonary vascular bed as described in rats by Seekamp et al. [28]. From a pathophysiological point of view, extravasation into interstitial lung tissue is critical in the development of pulmonary edema. We therefore adapted the flushing procedure of the pulmonary artery and were able to determine pulmonary vascular leakage appropriately. In pilot experiments, flushing of the pulmonary artery with $10 \mathrm{~cm} \mathrm{H}_{2} \mathrm{O}$ gravity and $3 \mathrm{ml}$ of Ringer's lactate was required to reduce background radiation. Intubation of the pulmonary artery under microscopic view proved to be easy and only one wild-type animal had to be excluded from further analysis due to technical difficulties during pulmonary artery perfusion.

Interestingly, Seekamp et al. [28] found in rats after $4 \mathrm{~h}$ of tourniquet-induced hindleg ischemia and $3 \mathrm{~h}$ of reperfusion considerably lower permeability index values in the lung $(0.35 \pm 0.05)$ than we determined in wild-type control mice $(0.92 \pm 0.29)$. We hypothesize that the two different ischemia-reperfusion injury models and the different species might explain the disparity of the results. Possibly rats are more resistant to remote pulmonary damage after lower torso ischemia-reperfusion injury than mice. Importantly, a pulmonary endothelial cell disruption was also found after $30 \mathrm{~min}$ of hepatic ischemia and $2 \mathrm{~h}$ of reperfusion. The endothelial damage was less pronounced than in the more severe lower torso ischemiareperfusion model but indicates ongoing systemic complement-mediated remote organ injury in the hepatic ischemia-reperfusion model.

Mice overexpressing $\mathrm{C} 1$ inhibitor were protected in the lower torso ischemia-reperfusion locally in the skeletal muscle and remotely in the lungs against ischemia-reperfusion injury. We concluded that human $\mathrm{C} 1$ inhibitor overexpression caused complement modulation and en- dothelial protection. As human $\mathrm{C} 1$ inhibitor is not only expressed in the serum of transgenic animals but also below the vascular endothelium [11], a local subendothelial complement inhibition might have enhanced the protection observed in transgenic animals.

In the hepatic ischemia-reperfusion model we also observed a local (hepatic and intestinal) and a remote pulmonary protection in transgenic animals. These results indicate that complement modulation by a transgenic approach can significantly reduce harmful sequelae of undesired complement activation during ischemia-reperfusion.

Transgenic animals might serve as tissue donors for allo- and xenotransplantation. $\mathrm{C} 1$ inhibitor overexpressing mice have already been used as recipients of rat cardiac xenografts, and it was shown that blockade of the classical complement cascade was transiently beneficial [29]. As the application of human C1 inhibitor was unproblematic in a variety of clinical disorders, one can speculate that a transgenic human $\mathrm{C} 1$ inhibitor overexpressing xenograft might also be tolerated well [3]. Furthermore, as coagulopathy seems to be another barrier to successful xenotransplantation [30], C1 inhibitor overexpression seems ideal due to its known capacity to inhibit the coagulation cascade and to prevent thrombosis [8]. With the technology of combining homologous recombination in fetal somatic cells with nuclear transfer [31], it may be worthwhile to induce overexpression of the human $\mathrm{C} 1$ inhibitor into a recombinant clonal pig donor organism. Control of the fluid-phase complement activation and inhibition of complement-mediated endothelial cell activation might contribute to long-term allo- and xenograft performance due to protection against inflammatory tissue injury.

In conclusion, we have developed surgical models of lower torso and liver ischemia-reperfusion injury in mice that allow simultaneous evaluation of local and remote tissue-specific endothelial disruption by the use of radioactively labelled albumin extravasation. Local and remote tissue injury was mitigated in transgenic human $\mathrm{C} 1$ inhibitor overexpressing mice in both series of ischemia-reperfusion indicating successful complement modulation by the transgenic approach.

\section{Acknowledgement}

We thank Dr. O. Stroka for critical revision of the manuscript. 


\section{References}

1 Homer-Vanniasinkam S, Crinnion JN, Gough MJ: Post-ischaemic organ dysfunction: A review. Eur J Vasc Endovasc Surg 1997;14:195203.

2 Seekamp A, Ward PA: Ischemia-reperfusion injury. Agents Actions Suppl 1993;41:137152.

3 Kirschfink M: C1-inhibitor and transplantation. Immunobiology 2002;205:534-541.

4 Asghar SS, Pasch MC: Therapeutic inhibition of the complement system. Y2K update. Front Biosci 2000;5:E63-81.

5 Hill $\mathrm{JH}$, Ward PA: The phlogistic role of $\mathrm{C} 3$ leukotactic fragments in myocardial infarcts of rats. J Exp Med 1971;133:885-900.

6 Riedemann NC, Ward PA: Complement in ischemia reperfusion injury. Am J Pathol 2003; 162:363-367.

7 Hugli TE: Biochemistry and biology of anaphylatoxins. Complement 1986;3:111-127.

8 Caliezi C, Wuillemin WA, Zeerleder S, Redondo M, Eisele B, Hack CE: C1-Esterase inhibitor: An anti-inflammatory agent and its potential use in the treatment of diseases other than hereditary angioedema. Pharmacol Rev 2000; 52:91-112.

9 Doekes G, van Es LA, Daha MR: C1-inactivator: Its efficiency as a regulator of classical complement pathway activation by soluble IgG aggregates. Immunology 1983;49:215-222.

10 Carter PE, Duponchel C, Tosi M, Fothergill JE: Complete nucleotide sequence of the gene for human $\mathrm{C} 1$ inhibitor with an unusually high density of Alu elements. Eur J Biochem 1991; 197:301-308.

11 Vinci G, Lynch NJ, Duponchel C, Lebastard TM, Milon G, Stover C, Schwaeble W, Tosi M: In vivo biosynthesis of endogenous and of human $\mathrm{Cl}$ inhibitor in transgenic mice: Tissue distribution and colocalization of their expression. J Immunol 2002;169:5948-5954.

12 Petersen SV, Thiel S, Jensen L, Vorup-Jensen $\mathrm{T}$, Koch C, Jensenius JC: Control of the classical and the MBL pathway of complement activation. Mol Immunol 2000;37:803-811.

13 Chan RK, Ibrahim SI, Ding GY, Verna N, Hechtman HB, Moore FD: Complement deposition from reperfusion injury to skeletal muscle occurs primarily on type II muscle fibers. J Surg Res 2003;114:283.
14 Austen WG Jr, Kobzik L, Carroll MC, Hechtman HB, Moore FD Jr: The role of complement and natural antibody in intestinal ischemia-reperfusion injury. Int $\mathrm{J}$ Immunopathol Pharmacol 2003;16:1-8.

15 Weiser MR, Williams JP, Moore FD Jr, Kobzik L, Ma M, Hechtman HB, Carroll MC: Reperfusion injury of ischemic skeletal muscle is mediated by natural antibody and complement. J Exp Med 1996;183:2343-2348.

16 de Smet BJ, de Boer JP, Agterberg J, Rigter G, Bleeker WK, Hack CE: Clearance of human native, proteinase-complexed, and proteolytically inactivated $\mathrm{C} 1$-inhibitor in rats. Blood 1993;81:56-61.

17 Bergamaschini L, Gobbo G, Gatti S, Caccamo L, Prato P, Maggioni M, Braidotti P, Di Stefano R, Fassati LR: Endothelial targeting with $\mathrm{C} 1$-inhibitor reduces complement activation in vitro and during ex vivo reperfusion of pig liver. Clin Exp Immunol 2001;126:412-420.

18 Horstick G, Berg O, Heimann A, Gotze O, Loos M, Hafner G, Bierbach B, Petersen S, Bhakdi S, Darius H, Horstick M, Meyer J, Kempski O: Application of C1-esterase inhibitor during reperfusion of ischemic myocardium: Dose-related beneficial versus detrimental effects. Circulation 2001;104:3125-3131.

19 Salvatierra A, Velasco F, Rodriguez M, Alvarez A, Lopez-Pedrera R, Ramirez R, Carracedo J, Lopez-Rubio F, Lopez-Pujol A, Guerrero R: $\mathrm{C} 1$-esterase inhibitor prevents early pulmonary dysfunction after lung transplantation in the dog. Am J Respir Crit Care Med 1997;155: 1147-1154.

20 Lehmann TG, Heger M, Munch S, Kirschfink $\mathrm{M}, \mathrm{Klar} \mathrm{E}$ : In vivo microscopy reveals that complement inhibition by $\mathrm{C} 1$-esterase inhibitor reduces ischemia/reperfusion injury in the liver. Transplant Int 2000;13(suppl 1):S547550 .

21 Nielsen EW, Mollnes TE, Harlan JM, Winn $\mathrm{RK}$ : C1-inhibitor reduces the ischaemia-reperfusion injury of skeletal muscles in mice after aortic cross-clamping. Scand J Immunol 2002; 56:588-592.

22 van den Berg CW, Aerts PC, van Dijk H: C1inhibitor prevents PEG fractionation-induced, EDTA-resistant activation of mouse complement. Mol Immunol 1992;29:363-369.
23 Kyriakides C, Wang Y, Austen WG Jr, Favuzza J, Kobzik L, Moore FD Jr, Hechtman HB Moderation of skeletal muscle reperfusion injury by a sLe(x)-glycosylated complement inhibitory protein. Am J Physiol 2001;281: C224-230.

24 Gibbs SA, Weiser MR, Kobzik L, Valeri CR, Shepro D, Hechtman HB: P-selectin mediates intestinal ischemic injury by enhancing complement deposition. Surgery 1996;119:652656.

25 Carter WO, Bull C, Bortolon E, Yang L, Jesmok GJ, Gundel RH: A murine skeletal muscle ischemia-reperfusion injury model: Differential pathology in BALB/c and DBA/2N mice. J Appl Physiol 1998;85:1676-1683.

26 Lindsay TF, Hill J, Ortiz F, Rudolph A, Valeri CR, Hechtman HB, Moore FD Jr: Blockade of complement activation prevents local and pulmonary albumin leak after lower torso ischemia-reperfusion. Ann Surg 1992;216:677683.

27 Kyriakides C, Austen WG Jr, Wang Y, Favuzza J, Moore FD Jr, Hechtman HB: Neutrophil mediated remote organ injury after lower torso ischemia and reperfusion is selectin and complement dependent. J Trauma 2000;48:32-38.

28 Seekamp A, Mulligan MS, Till GO, Ward PA Requirements for neutrophil products and $L$ arginine in ischemia-reperfusion injury. Am J Pathol 1993;142:1217-1226.

29 Hancock WW, Koyamada N, Miyatake T, Candinas D, Meo T, Carroll M, Bach FH: Delayed xenograft rejection in sensitized mice with genetically induced interruptions of complement activation. 4th International Congress for Xenotransplantation, Nantes, 1997, p O65.

30 Cowan PJ, Aminian A, Barlow H, Brown AA, Chen CG, Fisicaro N, Francis DM, Goodman DJ, Han W, Kurek M, Nottle MB, Pearse MJ, Salvaris E, Shinkel TA, Stainsby GV, Stewart AB, d'Apice AJ: Renal xenografts from tripletransgenic pigs are not hyperacutely rejected but cause coagulopathy in non-immunosuppressed baboons. Transplantation 2000;69: 2504-2515.

31 Prather RS, Hawley RJ, Carter DB, Lai L, Greenstein JL: Transgenic swine for biomedicine and agriculture. Theriogenology 2003;59: $115-123$ 